\title{
INHIBITORY ACTIVITY OF PYRIDINDOLOL ON $\beta$-GALACTOSIDASE
}

\author{
Michiniko Kumagai, Takaaki Aoyagi and Hamao Umezawa \\ Institute of Microbial Chemistry, \\ 14-23 Kamiosaki 3-chome, Shinagawa-ku, Tokyo, Japan
}

(Received for publication March 3, 1976)

\begin{abstract}
The activity of pyridindolol in inhibiting $\beta$-galactosidases obtained from various sources has been studied. Whereas acid bovine liver $\beta$-galactosidase (optimal $\mathrm{pH} 4.0$ ) was not affected by this compound, neutral bovine liver $\beta$-galactosidase ( $\mathrm{pH}$-optimum $=7.0$ ) was inhibited by pyridindolol in reaction mixtures of $\mathrm{pH} 4.0 \sim 5.0$. There was no inhibition at $\mathrm{pH}$ 7.0. The type of inhibition is non-competitive by formation of a pyridindolol-enzyme complex. Since $\beta$-galactosidases from other sources are not affected by pyridindolol, the inhibitory action of this compound seems to be rather specific for neutral bovine liver $\beta$-galactosidase.
\end{abstract}

$\beta$-Galactosidase (Lactase, EC 3.2.1.23) is a glycosidase which hydrolyzes $\beta$-galactoside bonds under releasing of galactose and is widely distributed among microorganisms, plants and animals. It was recently reported that $\beta$-galactosidase activity in fibroblasts shows a marked increase after transformation by oncogenic viruses, ${ }^{1}$ suggesting an involvement of this enzyme in oncogenicity.

There are many reports on $\beta$-galactosidase from Escherichia coli, ${ }^{2 \sim 5)}$ but there are very few on the action mechanism of this enzyme of animal origin.

As previously reported, ${ }^{6,7)}$ we isolated pyridindolol from Streptomyces alboverticillus culture filtrates as a specific inhibitor of neutral bovine liver $\beta$-galactosidase. In this paper, we report the action of this compound in detail and discuss its mechanism.

\section{Materials and Methods}

Pyridindolol (1-[1(R), 2-dihydroxyethyl]-3-hydroxymethyl-9H-pyrido (3, 4-b) indole) hydrochloride as shown below was prepared according to the method described in a previous paper. ${ }^{8,7)}$

Chemicals:

$p$-Nitrophenyl $\beta$-D-galactopyranoside (PNPG) and $o$-nitrophenyl $\beta$-D-galactopyranoside (ONPG) were purchased from BDH Chemical Ltd. (Poole, England), phenyl $\beta$-D-galactopyranoside from Nakarai Chemicals (Kyoto, Japan), 6bromo-2-naphthyl $\beta$-D-galactopyranoside and harman $\cdot \mathrm{HCl}$ from Sigma Chemical Co. (St. Louis, U.S. A.) and harmine $\cdot \mathrm{HCl}$ from Aldrich Chemical Co. (Milwaukee, U.S. A.).

Enzymes:<smiles>OCc1cc2c([nH]c3ccccc32)c(CO)n1</smiles>

Two types of bovine liver $\beta$-galactosidases which have reaction optima in acid or in neutral media were prepared according to the method described by CHYTIL ${ }^{8)}$ from the commercial preparation of bovine liver $\beta$-galactosidase purchased from Sigma. $\beta$-Galactosidases from other animals were prepared by methods described by HAY et al. ${ }^{p)}$ : Fresh bovine and pig organs were obtained from the slaughter-house; rats of the Wistar strain were decapitated and their organs were cooled at $0^{\circ} \mathrm{C}$. Human liver and small intestine were supplied by Dr. Y. Seyama, 
Department of Biochemistry, School of Medicine, the University of Tokyo; human placenta and amnion were kindly given by Dr. S. HAzATo, Department of Gynecology, Medical School of Toho University. The organs were minced, homogenized in cold water and subsequently incubated for 1 hour in acetate buffer of $\mathrm{pH} 5.2$ at $37^{\circ} \mathrm{C}$. The clear extracts were fractionated by addition of $\left(\mathrm{NH}_{4}\right)_{2} \mathrm{SO}_{4}$. Fractions which precipitated at $25 \sim 80 \%$ saturation were collected and kept frozen at $-20^{\circ} \mathrm{C}$ until used.

Assay of enzyme activities:

The following buffers were employed for reactions at various $\mathrm{pH}$-values: Phthalate-hydrochloric acid buffer ${ }^{10)}\left(0.2 \mathrm{M} \mathrm{KHC}_{8} \mathrm{H}_{4} \mathrm{O}_{4}+0.2 \mathrm{M} \mathrm{HCl}\right.$, diluted two fold) for $\mathrm{pH} 2.2 \sim 2.4$; citratephosphate buffer ${ }^{10)}\left(0.1 \mathrm{M}\right.$ citric acid $+0.2 \mathrm{M} \mathrm{Na}_{2} \mathrm{HPO}_{4}$, diluted two fold) for $\mathrm{pH} 2.4 \sim 7.0$; phosphate buffer ${ }^{10)}\left(0.2 \mathrm{M} \mathrm{NaH} \mathrm{NO}_{4}+0.2 \mathrm{M} \mathrm{Na}_{2} \mathrm{HPO}_{4}\right.$, diluted two fold) for $\mathrm{pH} 7.2 \sim 8.0$; trisacetate buffer $^{4)}(0.05 \mathrm{M})$ for $\mathrm{pH} 4.2 \sim 7.5$.

When PNPG or ONPG was used as substrate, the assay was carried out as described by AsP et al. ${ }^{11)}$ : Each tube contained $0.05 \mathrm{ml}$ of PNPG or ONPG $(0.05 \mathrm{M}), 0.4 \mathrm{ml}$ of buffer and $0.025 \mathrm{ml}$ water or inhibitor solution. After 3 -minute preincubation at $37^{\circ} \mathrm{C}$, the reaction was started by addition of $0.025 \mathrm{ml}$ of enzyme solution. After suitable time of incubation $(5 \sim 60$ minutes) at $37^{\circ} \mathrm{C}, 2 \mathrm{ml}$ of $0.4 \mathrm{M}$ glycine- $\mathrm{NaOH}$ buffer of $\mathrm{pH} 10.5$ were added and the amount of liberated $p$ - or $o$-nitrophenol was measured spectrophotometrically at $400 \mathrm{~nm}$ or $420 \mathrm{~nm}$, respectively.

When phenyl $\beta$-D-galactopyranoside was used as substrate, the assay was carried out as described by AsP. ${ }^{12)}$ The incubation mixture contained $0.05 \mathrm{ml}$ of phenyl $\beta$-D-galactopyranoside $(0.020 \mathrm{M}), 0.05 \mathrm{ml}$ buffer or buffer containing an inhibitor. After 3-minute incubation at $37^{\circ} \mathrm{C}$, the reaction was started by addition of $0.4 \mathrm{ml}$ of an enzyme solution preincubated in buffer. After 20 minutes at $37^{\circ} \mathrm{C}, 0.02 \mathrm{ml}$ of $1 \mathrm{~N} \mathrm{HCl}$ was added. The mixture was heated at $100^{\circ} \mathrm{C}$ for 2 minutes, neutralized by addition of $0.02 \mathrm{ml}$ of $1 \mathrm{~N} \mathrm{NaOH}$ and was subsequently prepared for the color reaction by addition of $1.5 \mathrm{ml}$ of $1 \mathrm{M}$ tris- $\mathrm{HCl}$ buffer $(\mathrm{pH} 8.5)$ containing 4-aminoantipyrine $(0.2 \mathrm{mg} / \mathrm{ml})$ and ethanol $(1.0 \%)$ followed by addition of $0.5 \mathrm{ml}$ of $0.4 \%$ potassium ferricyanide. The absorbance was read at $510 \mathrm{~nm}$.

When 6-bromo-2-naphthyl $\beta$-D-galactopyranoside was used as substrate, ${ }^{13)}$ the reaction mixture consisting of $0.01 \mathrm{ml}$ of $0.04 \mathrm{M}$ 6-bromo-2-naphthyl $\beta$-D-galactopyranoside and $0.06 \mathrm{ml}$ of buffer or buffer containing an inhibitor was preincubated at $37^{\circ} \mathrm{C}$ for 3 minutes. The reaction was started by addition of $0.03 \mathrm{ml}$ of the enzyme solution. After 60 minutes at $37^{\circ} \mathrm{C}$, the reaction was stopped by heating at $100^{\circ} \mathrm{C}$ for 2 minutes. The reaction mixture was cooled and $0.02 \mathrm{ml}$ of $1 \mathrm{M}$ tris- $\mathrm{HCl}$ buffer $(\mathrm{pH} 7.7)$ and $0.02 \mathrm{ml}$ of fast blue B salt solution $(1 \mathrm{mg} / \mathrm{ml})$ were added. After further addition of $0.04 \mathrm{ml}$ of $80 \%$ trichloroacetic acid solution, the mixture was shaken with $2 \mathrm{ml}$ of chloroform. After centrifugation at 3,000 rpm for 3 minutes, the chloroform layer was pippetted and the absorbance was read at $580 \mathrm{~nm}$.

Enzyme-inhibitor interaction:

The interaction between pyridindolol and the enzyme was studied by the gel filtration method of Fruton et al. ${ }^{14)}$ : A Sephadex G-15 column $(0.5 \times 150 \mathrm{~cm})$ was equilibrated with $0.05 \mathrm{M}$ citrate-phosphate buffer ( $\mathrm{pH} 4.2$ or 7.0 ) containing $2 \times 10^{-7} \mathrm{M}$ pyridindolol. Five mg of a purified neutral bovine liver $\beta$-galactosidase were dissolved in $1.0 \mathrm{ml}$ of the same buffer and after 30 minutes at room temperature, the enzyme solution was applied to the column. The elution was carried out with the same buffer and fractions of $1 \mathrm{ml}$ each were collected. Each fraction was diluted to $3 \mathrm{ml}$ with $0.1 \mathrm{~N} \mathrm{HCl}$ and the fluorescence intensity at $450 \mathrm{~nm}$ of each fraction was measured with a Hitachi 203 fluorescence spectrophotometer with exciting light of $380 \mathrm{~nm}$. The fluorescence is due to the presence of pyridindolol.

\section{Results}

In the previous report we employed a commercial preparation of bovine liver $\beta$-galactosidase. 
In order to elucidate the inhibition mechanism by pyridindolol, it was necessary to use a more purified enzyme. When the commercial bovine liver $\beta$-galactosidase obtained from Sigma was applied to a Sephadex G-100 column, and the enzymatic activity of eluted fractions was measured at $\mathrm{pH} 4.2$, using PNPG as substrate, two peaks appeared in fr. No. $48 \sim 59$ and fr. No. 59 78. The latter peak, representing neutral $\beta$-galactosidase, showed a higher activity than the former peak of acid $\beta$-galactosidase (Fig. 1). The activity of the neutral enzyme peak at pH 7.0 is also shown in Fig. 1. This enzyme was rechromatographed on a Sephadex G-200 column.

\section{$\mathrm{pH}$ Dependence of Enzyme Activity}

The $\mathrm{pH}$ activity relationship of the two $\beta$-galactosidases described above, using trisacetate buffer and citrate-phosphate buffer is
Fig. 1. Separation of the $\beta$-galactosidases of bovine liver on a Sephadex G-100 column

The enzymes were eluted from the column by $0.05 \mathrm{M}$ tris- $\mathrm{HCl}$ buffer, $\mathrm{pH} 7.0$, containing $0.1 \mathrm{M} \mathrm{KCl}$. Enzyme activity was measured at pH 4.2 with $0.05 \mathrm{~m}$ citrate-phosphate buffer (incubation time 1 hour) and at $\mathrm{pH} 7.0$ with $0.05 \mathrm{M}$ phosphate buffer (incubation time 0.5 hour) using $p$-nitrophenyl $\beta$-D-galactopyranoside as substrate. Absorbance at $280 \mathrm{~nm}$ was measured as the protein concentration.

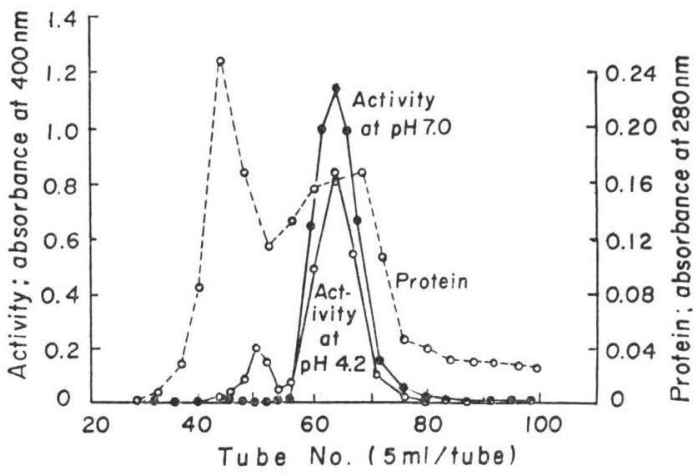

Fig. 2. $\mathrm{pH}$ Dependence of acid and neutral bovine liver $\beta$-galactosidases

Enzyme activities were measured by hydrolysis of $p$-nitrophenyl $\beta$-D-galactopyranoside $\left(5 \times 10^{-3} \mathrm{M}\right)$ in $0.04 \mathrm{M}$ tris-acetate buffer and $0.05 \mathrm{~m}$ citrate-phosphate buffer.

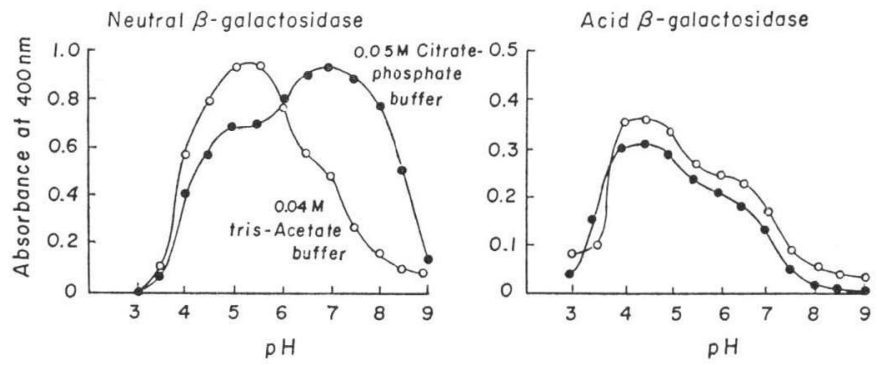

shown in Fig. 2. The acid $\beta$-galactosidase was found to have an optimum $\mathrm{pH}$ of 4.2 in both buffers. On the other hand, it was found that neutral $\beta$-galactosidase has different optimal $\mathrm{pH}$ values depending on buffers; $\mathrm{pH} 5.0$ in tris-acetate buffer and $\mathrm{pH} 6.5 \sim 7.0$ in citrate-phosphate buffer.

Inhibition of Neutral Bovine Liver $\beta$-Galactosidase by Pyridindolol

Fig. 3 shows the inhibition of neutral $\beta$-galactosidase by various concentrations of pyridindolol at $\mathrm{pH} 4.5$ and $7.0 ; 7.4 \times 10^{-6} \mathrm{M}$ of this compound showed $50 \%$ inhibition of the enzyme activity in the acid assay system. However, the activity of $\beta$-galactosidase in the neutral medium was inhibited only weakly by pyridindolol.

Influence of $\mathrm{pH}$ on the Inhibiting Activity of Pyridindolol

As shown in Fig. 4, the $\mathrm{pH}$ dependence curve of the inhibiting activity of pyridindolol is 
Fig. 3. Inhibition of neutral bovine liver $\beta$ galactosidase by varying concentrations of pyridindolol

Enzyme activities were measured by hydrolysis of $p$-nitrophenyl $\beta$-D-galactopyranoside $\left(5 \times 10^{-3} \mathrm{M}\right)$ in $0.04 \mathrm{M}$ tris-acetate buffer at $\mathrm{pH} 4.5$ and at $\mathrm{pH}$ 7.0. Percent inhibition was calculated as follows:

$$
\text { Inhibition }(\%)=\left[1-\left(I-I_{0} / S-S_{0}\right)\right] \times 100
$$

$S$ : Absorbance at $400 \mathrm{~nm}$ without pyridindolol

$S_{0}$ : Absorbance at $400 \mathrm{~nm}$ without pyridindolol blank

I: Absorbance at $400 \mathrm{~nm}$ within pyridindolol

$I_{0}$ : Absorbance at $400 \mathrm{~nm}$ within pyridindolol blank

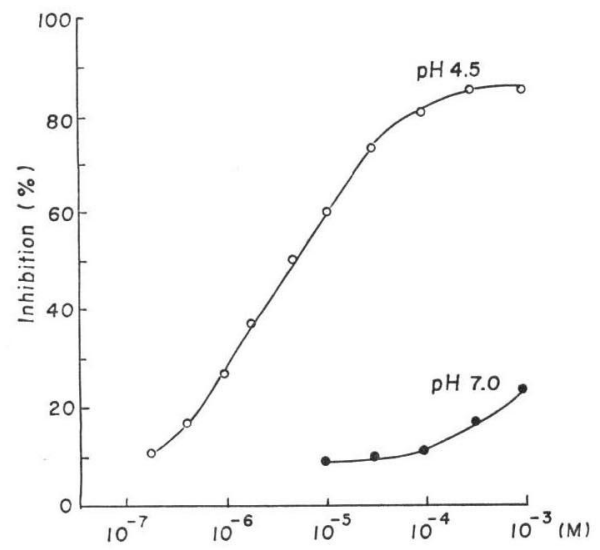

Fig. 4. The influence of $\mathrm{pH}$ on the inhibitory activity of pyridindolol against the bovine liver $\beta$-galactosidase and titration curve of pyridindolol

Enzyme activities were measured by hydrolysis of $p$-nitrophenyl $\beta$-D-galactopyranoside with $\left(2 \times 10^{-5} \mathrm{M}\right)$ or without pyridindolol $\cdot \mathrm{HCl}$ in $0.04 \mathrm{M}$ tris-acetate buffer. Percent inhibition was calculated as shown in Fig. 3. Titration curve was drawn by determination of pyridindolol absorbance at $307 \mathrm{~nm}$ in $0.05 \mathrm{M}$ citrate-phosphate buffer.

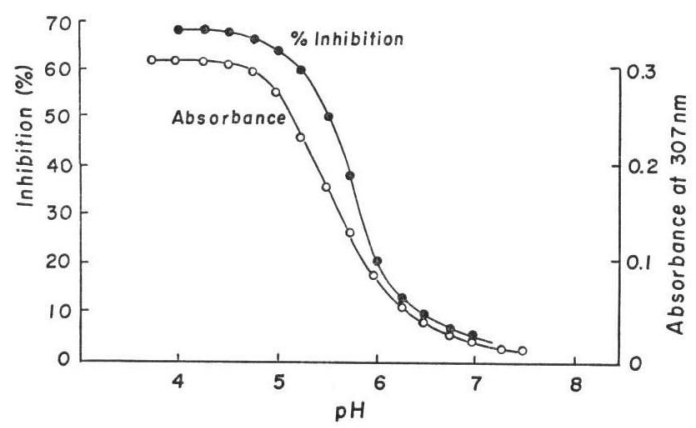

compared with the $\mathrm{pH}$ titration curve of the inhibitor, which indicates the relative amounts of the protonated and the base form of pyridindolol. The two curves closely resemble each other, indicating the same inflection point at pH 5.4 5.6 which corresponds to a pKá value (5.35) of pyridindolol. These results suggest that the protonated pyridindolol is more potent as an inhibitor than its unchanged base.

\section{Enzyme-Inhibitor Interaction}

The interaction between neutral bovine liver $\beta$-galactosidase and pyridindolol was studied by the gel filtration method. Fig. 5a shows the elution diagram at $\mathrm{pH}$ 4.2. The $\beta$-galactosidase was eluted in the $12 \mathrm{ml} \sim 16 \mathrm{ml}$ fractions, and the fluorescence intensity of pyridindolol decreased in the $27 \sim 37 \mathrm{ml}$ fractions. The decrease in the pyridindolol concentration suggests a binding of pyridindolol to the enzyme and an elution of this compound together with the enzyme. Fig. 5b represents the elution diagram at $\mathrm{pH}$ 7.0. In this case the enzyme was eluted at the same fraction as in the experiment at $\mathrm{pH} \mathrm{4.2,} \mathrm{but} \mathrm{a} \mathrm{decrease}$

Fig. 5. Elution diagrams of pyridindolol and $\beta$ galactosidase system from Sephadex G-15 upon $\mathrm{pH} 4.2$ and $\mathrm{pH} 7.0$

The interaction between the neutral bovine liver $\beta$-galactosidase and pyridindolol was carried out as described in the text. The elution diagram was obtained by analysis of individual fractions of effluent solution diluted 3 fold with $0.1 \mathrm{~N} \mathrm{HCl}$. The fluorescence emission intensity $\left(\lambda_{e m} 450 \mathrm{~nm}\right)$ was determined by use of exciting light of $380 \mathrm{~nm}$.

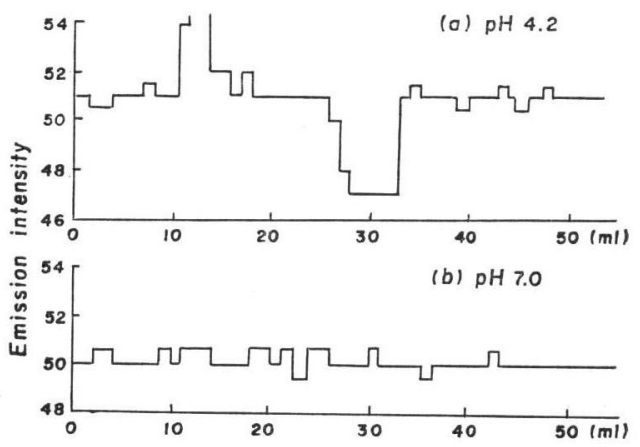


in the fluorescence was not observed, indicating a much weaker binding of pyridindolol to the enzyme at $\mathrm{pH} 7.0$ than at $\mathrm{pH}$ 4.2.

Effect of Pyridindolol on Other $\beta$-Galactosidase

Other $\beta$-galactosidases were prepared from small intestinal mucosa (human, bovine, pig, rat), kidney (bovine, pig), ovary (bovine, pig), heart (bovine), placenta (human) and amnion (human) and used for the study of the inhibiting effect of pyridindolol on the activities of these enzymes. As shown in Table 1, pyridindolol has no effect on these $\beta$-galactosidases except for the bovine liver $\beta$-galactosidase. Thus, pyridindolol is a specific inhibitor for neutral bovine liver $\beta$-galactosidase in acid reaction mixtures.

Table 1. Inhibitory effects of pyridindolol on various $\beta$-galactosidases

\begin{tabular}{|c|c|c|c|c|c|}
\hline \multicolumn{2}{|c|}{ Sources } & \multicolumn{4}{|c|}{ Inhibition $(\%)$} \\
\hline \multirow{2}{*}{ Organs } & \multirow{2}{*}{ Animals } & \multicolumn{2}{|c|}{$\mathrm{pH} 4.2$} & \multicolumn{2}{|c|}{$\mathrm{pH} 7.0$} \\
\hline & & $10^{-3} \mathrm{M}$ & $10^{-5} \mathrm{M}$ & $10^{-3} \mathrm{M}$ & $10^{-5} \mathrm{M}$ \\
\hline \multirow{4}{*}{ Liver } & Human & - & - & - & - \\
\hline & Bovine & 85 & 60 & 23 & 10 \\
\hline & Pig & - & - & - & - \\
\hline & Rat & - & - & - & - \\
\hline \multirow{4}{*}{$\begin{array}{l}\text { Small } \\
\text { intestinal } \\
\text { mucosa }\end{array}$} & Human & - & - & - & - \\
\hline & Bovine & - & - & 10 & - \\
\hline & Pig & - & - & - & - \\
\hline & Rat & - & - & - & - \\
\hline \multirow{2}{*}{ Kidney } & Bovine & - & - & - & - \\
\hline & Pig & - & - & - & - \\
\hline \multirow{2}{*}{ Ovary } & Bovine & - & - & - & - \\
\hline & Pig & - & - & - & - \\
\hline Heart & Bovine & - & - & - & - \\
\hline Placenta & Human & - & - & - & - \\
\hline Amnion & Human & - & - & - & - \\
\hline
\end{tabular}

Enzyme activities were measured by hydrolysis of $p$-nitrophenyl $\beta$-D-galactopyranoside $\left(5 \times 10^{-3} \mathrm{M}\right)$ in $0.05 \mathrm{M} \mathrm{pH} 4.2$ or $\mathrm{pH} 7.0$ citrate-phosphate buffer. Percent inhibition was calculated as described in Fig. 3. (-) indicates that the inhibition was less than $10 \%$.
Table 2. Inhibitory activities of pyridindolol on the enzymatic hydrolysis of four substrates at pH 4.2

\begin{tabular}{l|c|c}
\hline \multirow{2}{*}{ Substrates } & \multicolumn{2}{|c}{ Inhibition } \\
\cline { 2 - 3 } & $\%$ with $10^{-5} \mathrm{M}$ & $\mathrm{I}_{50} \mathrm{M}$ \\
\hline $\begin{array}{l}p \text {-Nitrophenyl } \beta \text {-D- } \\
\text { galactopyranoside }\end{array}$ & 60 & $7.4 \times 10^{-8}$ \\
$\begin{array}{l}\text { o-Nitrophenyl } \beta \text {-D- } \\
\text { galactopyranoside }\end{array}$ & 56 & $7.6 \times 10^{-6}$ \\
$\begin{array}{l}\text { Phenyl } \beta \text {-D } \\
\text { galactopyranoside }\end{array}$ & 26 & $5 \times 10^{-2}$ \\
$\begin{array}{l}\text { 6-Bromo-2-naphthyl } \\
\beta \text {-D-galactopyranoside }\end{array}$ & - & - \\
\hline
\end{tabular}

Enzyme activities were measured with $p$-nitrophenyl $\beta$-D-galactopyranoside $\left(5 \times 10^{-3} \mathrm{M}\right), o$-nitrophenyl $\beta$-D-galactopyranoside $\left(5 \times 10^{-3} \mathrm{M}\right)$, phenyl $\beta$-D-galactopyranoside $\left(2 \times 10^{-3} \mathrm{M}\right)$ and 6-bromo2-naphthyl $\beta$-D-galactopyranoside $\left(4 \times 10^{-3} \mathrm{M}\right)$ in $0.05 \mathrm{M}$ citrate-phosphate buffer at $\mathrm{pH} 4.2$. Percent inhibitions were calculated as shown in Fig. 3. $\mathrm{I}_{50}(\mathrm{M})$ were derived graphically. $(-)$ indicates that the inhibition observed was less than $10 \%$.

Fig. 6. Reciprocal plots for the inhibitory effect of pyridindolol on neutral bovine liver $\beta$ galactosidase

Enzyme activities were measured by hydrolysis of $p$-nitrophenyl $\beta$-D-galactopyranoside $\left(10^{-2} \mathrm{M}, 5 \times 10^{-3} \mathrm{M}, 3.33 \times 10^{-3} \mathrm{M}, 2.5 \times 10^{-3} \mathrm{M}\right.$, and $\left.2 \times 10^{-3} \mathrm{M}\right)$ in the presence of pyridindolol $\cdot \mathrm{HCl}$ $\left(D=5 \times 10^{-6} \mathrm{M}, \quad \mathrm{C}=2.5 \times 10^{-8} \mathrm{M}, \quad B=1.25 \times 10^{-8} \mathrm{M}\right.$ and $A=0$ ) in $0.04 \mathrm{M}$ tris-acetate buffer $\mathrm{pH} 4.5$.

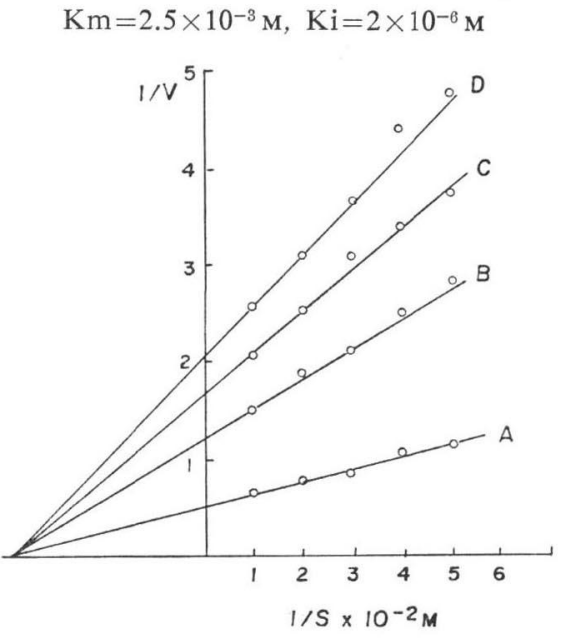


Effect of Substrates on the Inhibitory Activity of Pyridindolol

Various kinds of substrates were examined for their inhibition of pyridindolol action. Table 2 shows the percent inhibition of the enzymatic activity by pyridindolol at the concentration of $10^{-5} \mathrm{M}$ and the $I_{50}$ values which indicate the molar concentration of the inhibitor for $50 \%$ inhibition. When PNPG or ONPG were employed, the $I_{50}$ values were approximately $7.5 \times 10^{-6} \mathrm{M}$. But, when phenyl $\beta$-D-galactopyranoside was used as a substrate, the $I_{50}$ increased to the order of $10^{-2} \mathrm{M}$.

\section{Kinetic Parameters}

A LineweAVER-BURK plot of the inhibitory action of pyridindolol on neutral bovine liver $\beta$-galactosidase using $\mathrm{pH} 4.5$ tris-acetate buffer is shown in Fig. 6. As the concentration of substrate increased, the slope of the line also increased. Therefore, it is clear that pyridindolol inhibits $\beta$-galactosidase in a non-competitive manner. The $\mathrm{Km}$ and $\mathrm{Ki}$ values with PNPG as substrate are $2.5 \times 10^{-3} \mathrm{M}$ and $2 \times 10^{-8} \mathrm{M}$, respectively.

Table 3. Inhibition of $\beta$-galactosidase by pyridindolol and related compounds

\begin{tabular}{|c|c|c|c|c|c|}
\hline \multirow{2}{*}{ Compound } & \multirow{2}{*}{ Structure } & \multirow{2}{*}{ MW } & \multirow{2}{*}{ pKá } & \multicolumn{2}{|c|}{ Inhibition $\%$} \\
\hline & & & & $10^{-3} \mathrm{M}$ & $10^{-5} \mathrm{M}$ \\
\hline Pyridindolol $\cdot \mathrm{HCl}$ & & 294.8 & 5.35 & 85 & 57 \\
\hline Pyridindolol triacetate & & 384.8 & & - & - \\
\hline $\mathrm{Harman} \cdot \mathrm{HCl}$ & & 218 & 6.10 & 21 & - \\
\hline Harmine $\cdot \mathrm{HCl} \cdot \mathrm{H}_{2} \mathrm{O}$ & & 248 & $\begin{array}{r}6.50 \\
10.70\end{array}$ & 17 & - \\
\hline $\mathrm{Harmol} \cdot \mathrm{HCl} \cdot \mathrm{H}_{2} \mathrm{O}$ & & 252.7 & $\begin{array}{r}6.70 \\
11.20\end{array}$ & - & - \\
\hline 2, 6-Pyridine dimethanol & & 139.2 & 4.35 & - & - \\
\hline Ethylene glycol & $\mathrm{HOCH}_{2}-\mathrm{CH}_{2} \mathrm{OH}$ & 62.1 & & - & - \\
\hline Propylene glycol & $\begin{array}{c}\mathrm{CH}_{3} \mathrm{CH}-\mathrm{CH}_{2} \mathrm{OH} \\
\mathrm{OH}\end{array}$ & 76.1 & & - & - \\
\hline
\end{tabular}

Enzyme activities were measured by hydrolysis of $p$-nitrophenyl $\beta$-D-galactoside $\left(5 \times 10^{-3} \mathrm{M}\right)$ in the presence $\left(10^{-3} \mathrm{M}\right.$ and $\left.10^{-5} \mathrm{M}\right)$ and in the absence of compounds in $0.05 \mathrm{M} \mathrm{pH} 4.2$ citrate-phosphate buffer. Percent inhibitions were calculated as described in Fig. 3. 
The Activity of Pyridindolol Analogs

The inhibitory activities of pyridindolol analogs in concentrations of $10^{-3} \mathrm{M}$ and $10^{-5} \mathrm{M}$ at pH 4.2, their chemical structure and pKá values are shown in Table 3. The results suggest that both hydroxy groups and the $\beta$-carboline skeleton are essential for the activity of pyridindolol in inhibiting neutral $\beta$-galactosidase in acid reaction media.

Influences of Metal Ions, Cysteine and Chelating Agents

Studies on the effects of various kinds of metal ions on the inhibitory activity of pyridindolol against the neutral bovine liver $\beta$-galactosidase revealed that generally metal ions $\left(10^{-4} \mathrm{M}\right)$ did not interfere with the action of pyridindolol, except that mercuric ions inhibited the $\beta$ galactosidase. L-Cysteine $\left(10^{-4} \mathrm{M}\right)$ and EDTA $\left(10^{-4} \mathrm{M}\right)$ had also no effect on the inhibitory activity of pyridindolol.

\section{Discussion}

The data described above indicate that hydroxy groups and the $\beta$-carboline skeleton of pyridindolol are essential for the inhibitory activity on the enzymatic action of neutral bovine liver $\beta$-galactosidase. But, at present, we cannot explain why pyridindolol is a specific inhibitor of only neutral bovine liver $\beta$-galactosidase and why it has no effect on the enzymes for other sources. HAY et al. ${ }^{\vartheta)}$ reported that bovine liver $\beta$-galactosidase and kidney $\beta$-galactosidase are similar and classified these enzymes into the same category. However, the data described in this paper indicate that bovine liver $\beta$-galactosidase, at least the neutral enzyme, differs from bovine kidney $\beta$-galactosidase in its behavior against the inhibitor.

WALLENFELS et al..$^{5)}$ summarized that the hydrolysis of ONPG by $\beta$-galactosidase from $E$. coli $\mathrm{K}-12$ is inhibited competitively by D-galactose, lactose and some other $\beta$-D-galactosides. They also summarized that phenyl thiogalactoside has almost the same affinity for the enzyme of E. coli ML as phenyl $\beta$-D-galactoside. HAY et al.$^{\left.{ }^{9}\right)}$ reported that galactono $(1 \rightarrow 4)$ lactone inhibits the $\beta$-galactosidase competitively. LeE et al. ${ }^{16)}$ described that D-galactal inhibits various $\beta$-galactosidases and that its inhibition is competitive or of a type of hyperbolic competition. These inhibitors are all substrate analogs. WALlENFELs et al. ${ }^{5)}$ suggested that the inhibitory actions of these compounds are probably due to the formation of a half-chair conformation and inhibitors in this conformation resemble the carbonium ion of the substrate in the transition state. The inhibitors are supposed to bind to a negative charge group in the active site of the enzyme.

Although pyridindolol cannot form a half-chair conformation for its very rigid structure, the data described above indicate that the protonated pyridindolol is active and binds to a negative group in the neutral bovine liver $\beta$-galactosidase. Similar observations were made in the case of the eserine, which is a competitive inhibitor of acetylcholine esterase. ${ }^{17)}$ The noncompetitive type of inhibition and the behavior on gel filtration of the neutral bovine liver $\beta$ galactosidase-pyridindolol mixture indicates the formation of a pyridindolol-enzyme complex.

\section{References}

1) Bosman, H. B.: Elevated glycosidase and proteolytic enzyme in cells transformed by RNA tumor virus. Biochim. Biophys. Acta 264: 339 343, 1972

2) LederberG, J.: The beta-D-galactosidase of Escherichia coli, strain K-12. J. Bact. 60: 381 392, 1950

3) Wallenfels, K.; J. Lehmann \& O.P. Malhotra: Untersuchungen über milchzuckerspaltende Enzyme. VII. Die Spezifität der $\beta$-Galactosidase von E. coli ML 309. Biochem. Zeitschrift 333: 209 225, 1960

4) Wallenfels, K. \& P.O. Malhotra: Galactosidase "Advance Carbohydrate Chem." 16: pp. 239 298, Academic Press, 1961 
5) Wallenfels, K. \& R. Weil: $\beta$-Galactosidase "The Enzyme," 3rd ed., Vol. VII, pp. 617 663, Adademic Press, 1972

6) Aoyagi, T.; M. Kumagai, T. Hazato, M. Hamada, T. Takeuchi \& H. Umezawa: Pyridindolol, a new $\beta$-galactosidase inhibitor produced by Actinomycetes. J. Antibiotics 28: 555 557, 1975

7) Kumagai, M.; H. Naganawa, T. Aoyagi, H. Umezawa, H. Nakamura \& Y. Iitaka: Structure of pyridindolol, inhibitor of $\beta$-galactosidase. J. Antibiotics 28: 876 880, 1975

8) Chytil, F.: Mammalian $\beta$-galactosidase. Biochem. Biophys. Res. Commun. 19: 630 636, 1965

9) Levvy, G. A.; A. McAllen \& A. J. HAY: Inhibition of glycosidase by aldonolactones of corresponding configuration. 3. Inhibitor of $\beta$-D-galactosidase. Biochem. J. 82: 225 232, 1962

10) Gomori, G.: Preparation of buffer for use in enzyme studies. "Methods in Enzymology," Vol. 1, pp. 138 146, Academic Press, 1955

11) DAHLQvist, A. \& G. Asp: Rat small-intestinal $\beta$-galactosidases influence of $\mathrm{pH}$ on the hydrolysis of different substrate. Biochem. J. 103: 86 89, 1967

12) Asp, N. G.: Improved method for the assay of phenylglycosidase activity with a 4-aminoantipyrine reagent. Anal. Biochem. 40: 281 286, 1971

13) Dahlqvist, A.; B. Bull \& B. E. Gustafsson: Rat intestinal 6-bromo-2-naphthyl-glycosidase and disaccharidase activities. 1. Enzymic properties and distribution in the digestive tract of conventional and germ-free animals. Arch. Biochem. Biophys. 109: 150 158, 1965

14) Fatrclough, C.H. \& J.S. Fruton: Peptide-protein interaction as studied by gel filtration. Biochemistry 5: 673 683, 1966

15) Lineweaver, H. \& D. Burk: The determination of enzyme dissociation constants. J. Am. Chem. Soc. 56: $658 \sim 666,1934$

16) LEe, Y.C.: Inhibition of $\beta$-galactosidase by D-galactal. Biochem. Biophys. Res. Commun. 35: $161 \sim 167,1969$

17) Wilson, I. B. \& F. Bergman: Studies on cholinesterase. VII. The active surface of acetylcholine esterase derived from effects of $\mathrm{pH}$ on inhibitors. J. Biol. Chem. 185: 479 489, 1950 